\title{
Modisco With Moringa Leaf for Improving Childhood's Nutritional Status
}

\author{
Indah Muflihatin* \\ Department of Health \\ Politeknik Negeri Jember \\ Jember, Indonesia \\ indah_muflihatin@polije.ac.id
}

\author{
Veronika Vestine \\ Department of Health \\ Politeknik Negeri Jember \\ Jember, Indonesia \\ veronikavestine@polije.ac.id \\ Selvia Juwita Swari \\ Department of Health \\ Politeknik Negeri Jember \\ Jember, Indonesia \\ selvia@polije.ac.id
}

\author{
Gandu Eko JS \\ Department of Health \\ Politeknik Negeri Jember \\ Jember, Indonesia \\ gandu.eko.js@polije.ac.id
}

\begin{abstract}
Child growth is recognized as an important indicator of nutritional and health status. But in fact, there are still some cases of undernutrition in some areas of Jember. This is certainly a challenge for health providers because the lack of nutrients that occur in this golden period is irreversible. This research aims to analyze the effects of modisco with moringa leaf for improving the childhood's nutritional status. It was a quantitative research and conducted by using quasiexperimental study. This research used pre-post tests design for experiment and control groups. Data from 40 children (20 from modisco group and 20 from the control group) were analyzed by using paired t-test and simple logistic regression. After one week of treatment, the mean of child weight significantly increased in intervention groups (mean gain weight 0.57 kilogram, $\mathrm{p}=$ 0.000), whereas the weight score remained unchanged in the control group (mean gain weight 0.05 kilogram, $p=0.066$ ). The result also showed that there was a significant positive effect of the modisco with moringa leaf for increasing child's body weight $(p=0.026$, Exp. $B=56,6)$. It was indicated that the children who were given modisco with moringa leaf for 7 days, potentially had 56,6 times greater for increasing their weight than those who were not given. It could be conduded that the consumption of Modisco with moringa leaf had a beneficial effect to improve the childhood's nutritional status
\end{abstract}

Keywords-modisco, moringa, child, body, weight

\section{INTRODUCTION}

Nutrition is an important factor in the promotion and maintenance of good health [1]. Undernutrition and hidden hunger are threatening child survival, growth, and development. Globally 1 in 3 children are have undernourished, and 1 in 2 children are suffering from hidden hunger [2]. According to the monitoring of nutritional status in 2017, Indonesia is considered to have a high prevalence of stunting (29.6\%), the medium prevalence of underweight $(17.9 \%)$, and poor of wasting $(9.5 \%)$ [3][4]. Then Jember Regency is one of 100 district priorities for poverty handling and malnutrition. It has a very high stunting prevalence $(44.1 \%)$, the medium prevalence of underweight $(11.7 \%)$, and the number of children suffering from deficiencies is 128 toddlers [5]. So, there is an important issue about nutritional status in Indonesia, also in Jember regency.

Inadequate nutrition intake and the incidence of infection is the direct cause of malnutrition in children [6]. While inadequate food supply, inadequate parenting practice, poor sanitation, and health services limited access are the indirect cause of malnutrition in the family level [7]. In the short term, poor nutrition can contribute to brain development disruption, physical growth disorders, also metabolic disorder and long term effect can be reduced cognitive abilities, also developing high risk of some illnesses and other health problems such as: type-2 diabetes, overweight, heart, blood vessel disease, cancer, and stroke [8].

A possible solution for overcoming malnutrition in children is supplementary feeding [9]. Ready to use therapeutic foods (RUTF) such as Modified Dried Skimmed Milk Coconut Oil (Modisco). Modisco is rich in energy and protein so it can improve nutritional status or increase children's weight quickly [10][11]. Based on the research, giving modisco to undernutrition children has a significant effect on their body weight gain and body length [12][13][14].

Modisco is therapeutic liquid food recommended by WHO [10]. It has been tested and meets dietary requirements from Minister of Health decree (Keputusan Menteri Kesehatan or Kepmenkes) no.5/2016 on standard nutritional supplementation product [9][11]. Modisco is a highly nutritious formula [15]. The primary source of energy and protein in modisco are skim milk, sugar, and oil or margarine [11]. Basic of modisco formula contains energy (100-130 kilocalories), protein (3-3.5 grams), and fat (5-7.5 grams) per serving [15]. Modisco has proven to be an alternative formula to help bodyweight gain for undernutrition children [16]. Also can be a food supplement for completing the daily nutrient for improving childhood's nutritional status [11]. Based on previous research, it found that 22 children's bodyweight significantly increased after they had given modisco formulas [12].

Moringa Oleifera is a drought-resistant and fast-growing tree which is present in nearly all tropical and sub-tropical 
countries [17]. As a source of good nutrition, moringa leaf found containing many essential nutrients [18]. Moringa oleifera one of a plant can be cultivated in all regions in Indonesia easily [19]. It is a natural variety of the genus Moringa and belonging to family Moringaceae. In English, commonly known as Horseradish tree, Drumstick tree, Never Die tree, West Indian Ben tree, and Radish tree [20]. Moringa leaves are compound $20-60 \mathrm{~cm}$ long with each pinnate bearing 4-6 pairs of leaflets that are dark green, elliptical to obovate [21]. It has a slightly bitter taste, are neutral and non-toxic [19]. Moringa leaves can be produced intensively in a familysize small garden [18].

The benefits of consuming Moringa leaves have been tested in the AGADA (Alternative Action for African Development) program. Moringa leaves reported used to prevent or treat malnutrition in pregnant or breastfeeding women also their children [22]. The pods and leaves of Moringa contain of high amount vitamins, minerals, amino acid, anti-inflammatory nutrients, beta-carotene, antioxidants, omega 3 and 6 fatty acids [18][23]. Because of the nutritional values of Moringa, it has potential benefits in malnutrition [24]. The leaves can be easily dried into powder form. Then the powder can be added to milk, soup, tea, sauce, and other food as a dietary supplement or additional foods [17][25]. Previous research in Sinegal indicated that children maintained or increased their weight and improved overall health by using Moringa leaf powder in foods [24][26].

We developed an intervention supplementary food modisco with moringa leaf (Moringa Oleifera) that aims to promote healthy and nutritious eating in children. The main objective of this study was to evaluate the effect of this intervention on children's body weight gain, in Jember, Indonesia. The research questions for this study were: Does give modisco with moringa leaf powder for 7 days is able to increase the bodyweight of children ages 7-12 years?

\section{METHOD}

\section{A. Research Design}

To investigate the effect of the modisco with moringa leaf for children's body weight gain, a field quasi-experimental study was carried among children ages 7-12 years, and based on a pretest-postest control group design. The modisco with moringa leaf as an intervention carried out by the author.

\section{B. Participant}

The study was conducted in the outpatient service of the Polres Pratama Clinic in Jember, Indonesia. The research subjects were selected from among children aged 7-12 years and were not currently suffering from an infectious disease. A systematic random sampling method was used to select the participants. The sample size was calculated for an experimental study with the following assumptions, Type 1 error $5 \%$ and power of study $90 \%$. A total of 40 children aged $7-12$ years were randomly assigned to Moringa group $(n=20)$ or Control group $(n=20)$, using a computer-generated list.

\section{Procedure, data collection and statistical analysis}

Participants in the intervention group received the modisco with moringa leaf formula as intervention program, while participants in the control group received no intervention program. The moringa leaf formula consist of 13 grams fat, 243 grams dried skim milk, 122 grams vegetable oil and 122 grams sugar per serving per day. Before the implementation of the intervention program, all participants body weight was observed. One week after intervention program, their body weight was re-measured. Paired t-test conducted to test for comparison body weight between pre and post intervention in both of group and independent t-test conducted for comparing base-line body weight score. The Kolmogorov-Smirnov goodness-of-fit test was used for testing normality before data were analyzed by t-test. Simple Logistic Regression models were used in this study to evaluate the effect of modisco with moringa leaf powder on children's body weight gain.

\section{RESULT}

\section{A. Result}

In total, 40 children aged 7-12 years were studied, of whom 20 were in the intervention group and 20 were in the control group. Table 1. shows the baseline body weight of children who entered the intervention group were higher (mean 29.48 kilogram) than of those who participated in the control group (mean 27.60 kilogram). It also shows one week after the intervention and their body weight was re-measured, the scores of the body weight show that there is a significant increase in the intervention group ( $p$-value $=0.000)$, but an increased non-significant in the control group ( $\mathrm{p}$-value $=0.066$ ).

TABLE I. AVERAGE SCORES OF CHILDREN'S BODY WEIGHT FOR INTERVENTION AND CONTROL GROUP

\begin{tabular}{|c|c|c|c|c|c|c|}
\hline \multirow{2}{*}{$\begin{array}{c}\text { Body } \\
\text { Weight }\end{array}$} & \multicolumn{3}{|c|}{ Intervention Group $(\mathbf{n}=\mathbf{2 0})$} & \multicolumn{3}{|c|}{ Control Group $(n=20)$} \\
\hline & Mean & $S D$ & p-value & Mean & $S D$ & $p$-value \\
\hline Base-line & 29.48 & 7.47 & 0.000 & 27.60 & 6.46 & 0.066 \\
\hline Post-test & 30.13 & 7.87 & & 27.65 & 6.42 & \\
\hline
\end{tabular}

Table II. describes that body weight was not significantly different before the intervention. But after 7 days intervention period, we found that the children's body weight gain in the intervention group was higher (mean 0.65 kilograms) than of those who participated in the control group (mean 0.05 kilogram). The logistic regression analysis in table II. shows that there was a significant positive effect of the modisco with moringa leaf powder for increasing children's body weight $(\mathrm{p}=$ 0.026, Exp.B=56,6). It was indicated that the child who given modisco with moringa leaf powder for 7 days, potentially has 56,6 times greater for increasing their weight than those of no given.

TABLE II. LOGISTIC REGRESSION ANALYSES EFFECT OF MODISCO WITH MORINGA LEAF FOR INCREASING BODY WEIGHT GAIN

\begin{tabular}{|c|c|c|c|c|c|}
\hline \multirow{2}{*}{ Participant } & Base-line & \multicolumn{4}{|c|}{ Weight Gain } \\
\cline { 2 - 5 } & $\boldsymbol{p}$-value & Mean & SD & p-value & Exp.B \\
\hline $\begin{array}{c}\text { Intervention group } \\
(\mathrm{n}=20)\end{array}$ & 0.260 & 0.65 & 0.68 & & \\
\cline { 1 - 2 } $\begin{array}{c}\text { Control group } \\
(\mathrm{n}=20)\end{array}$ & & 0.05 & 0.11 & & 56.626 \\
\hline
\end{tabular}

\section{B. Discussion}

The growth of children's age 7-12 years is the most rapid period of growth after the toddler's growth period. Proper 
nutrition both the number and the type of food, affecting the growth process [27]. Preliminary studies suggest that children ages 6-12 years understand that "good" and "bad" foods can influence health and growth [28]. So the addition of Moringa flour in this study which is most preferred or accepted based on external and internal attributes [29].

The result found a baseline body weight of childrens who entered the intervention group were higher than of those who participated in the control group. But statistically test show that both of group had same condition before that intervention. Healthy child development depends on the quality of stimulation, support, and care from the social environment where children live. Nurturing qualities of family environments include parenting skills, nutritional supplementation and childcare arrangements [30].

This study found that the children's body weight gain in the intervention group was higher (mean 0.65 kilograms) than of those who no given (mean 0.05 kilogram). These findings are consistent with a recent review report in which giving modisco was significant to increase body weight in children [12][18]. As a nutrient-dense food, modisco contains high proteins, high calories, adequate vitamins, minerals, and fluids that easy to absorb [31]. It known that they are the main nutrients to support cellular activity including cell growth [32].

This study also found a daily addition of 13 grams of moringa leaf powder in modisco for 7 days was able to increase the body weight of children ages 7-12 years. The results of this study are consistent with studies in Bangalore India, which $60 \%$ of children who were given 15 grams of Moringa leaf powder twice a day for two months improving their nutritional status from grade I protein energy malnutrition to normal nutritional status [33]. Other studies in Burkina Faso also shown that malnourished children who were given 10 grams of Moringa leaf powder daily for 6 months improved their anthropometric status [34]. Supplementation of 5-10 grams of moringa oleifera powder per daily for 14 days has been able to increase body weight by 0.53 kilograms on children in Kupang Regency [35]. The beneficial effect of Moringa leaves apart from gaining weight, it also reported increase $\mathrm{HB}$ levels, reduce disease, and improve the health among children in Tanzania [36].

Using Modisco with moringa leaf powder has benefit for increasing children's body weight, so it has probability to combat malnutrition. The major advantage by using moringa oleifera in this study is the fact that that's leaves easy to find because it is Indonesian local cultivate. Moringa leaves also rich in macro and micro nutrients which are especially important for children health and development.

\section{CONCLUSION}

It can be concluded as follows:

- The child who given modisco with moringa leaf powder for 7 days, potentially has 56,6 times greater for increasing their weight than those of no given.

- Daily addition of moringa leaf powder in modisco was able to increase the body weight of children ages 7-12 years.
- Modisco with Moringa leaves can be used as a menu option to improve the nutritional status of malnutrition children.

It could be suggested that the consumption of Modisco with moringa leaf had a beneficial effect to improve the childhood's nutritional status. even so, further studies that conduct among children with undernutrition are needed to look at the effect of modisco and moringa to improving their nutritional status.

\section{REFERENCES}

[1] E. Alfadhli, "Macronutrients imbalance and micronutrient deficiencies among healthy Saudi physicians in Al Madina, Saudi Arabia," Saudi J. Med. Med. Sci., vol. 4, no. 3, p. 192, 2016, doi: 10.4103/1658$631 \times .188264$.

[2] UNICEF, Children , food and nutrition: growing well in a changing world. 2019.

[3] Doddy Izwardi, "The Stategy and policy to involve property in Indonesia," 2019.

[4] WHO, "Interpretation Guide," $2012 . \quad$ doi: 10.1159/000362780.Interpretation.

[5] TNP2K, "Pemilihan 10 Desa Prioritas Di 100 Kabupaten/Kota Prioritas Penanganan Kemiskinan Dan Stunting," Kementrian Koordinator Bidang Pembangunan Manusia dan Kebudayaan, Kementrian PPN/Bappenas., 2017. http://www.cegahstunting.id (accessed Mar. 16, 2020).

[6] UNICEF, "UNICEF' s approach to scaling up nutrition," 2012.

[7] WHO, Reducing stunting in children. 2018.

[8] Kemenkes, "Situasi Balita Pendek," 2016.

[9] Kemekes RI, "Peraturan Menteri Kesehatan Republik Indonesia Nomor 51 Tahun 2016 Tentang Standar Produk Suplementasi Gizi," 2016.

[10] G. S. Pontang and S. Maryanto, "formulation with soybean ( glycine max ) flour addition Protein quality of modified dried skimmed milk coconut oil ( modisco ) III formulation with soybean ( glycine max ) flour addition," in International Conference on Life Sciences and Technology (ICoLiST), 2020, pp. 1-4, doi: 10.1063/5.0002545.

[11] A. C. Adi, Modisco Makanan Penambah Berat Badan Anak. 2001.

[12] N. Hidayah, Irawati, I. Puspitasari, and D. A. Sari, "The effectiveness of modified dried skimmed milk (MODISCO) to the body weight of under nutrition and malnutrition children," J. Phys. Conf. Ser., vol. 1477, no. 6, 2020, doi: 10.1088/1742-6596/1477/6/062003.

[13] N. E. Mardliyana and S. Indrawati, "The Influence Of Granting Modisco With Weight Changes On Toddlers Ages1-5 Years at Posyandu Persada Sumberwaru Wringinanom- Gresik - East Java Indonesia," in 4th Asian Academic Society International Conference (AASIC) 2016, 2016, no. 2013, pp. 355-358.

[14] S. Maryanto, G. S. Pontang, and M. E. Nurina, "Modisco III formulation for combating severe malnutrition," Proc. 3RD Int. Semin. Metall. Mater. Explor. New Innov. Metall. Mater., vol. 2232, no. April, p. 030002, 2020, doi: 10.1063/5.0002539.

[15] M. E. Nurina, S. Maryanto, and G. S. Pontang, "The Effect of Giving Modified Modisco With Soybeans Against Growth on Protein Enery Malnutrition Rats," J. Gizi dan Kesehatan., vol. 12, no. 27, pp. 59-64, 2020.

[16] A. Arolyumna, S. Prihatin, and D. N. Subandriani, "Pengaruh Pemberian Es Krim Modisco Terhadap Kenaikan Berat Badan Pada Balita Gizi Kurang,” J. Ris. Gizi, vol. 4, no. 1, pp. 49-54, 2016.

[17] L. J. Fuglie, THE MORINGA TREE A local solution to malnutrition?, no. 221.2005

[18] A. F. A. Razis, M. D. Ibrahim, and S. B. Kntayya, "Health benefits of Moringa oleifera," Asian Pacific J. Cancer Prev., vol. 15, no. 20, pp. 8571-8576, 2014, doi: 10.7314/APJCP.2014.15.20.8571.

[19] E. Nurcahyati, Khasiat Dahsyat Daun Kelor, I. Jakarta: Jendela Sehat, 2014.

[20] D. Krisnadi, Kelor Super Nutrisi. Blora: Pusat Informasi Dan Pengembangan Tanaman Kelor Indonesia Lembaga Swadaya Masyarakat - Media Peduli Lingkungan (LSM-MEPELING), 2015. 
[21] Q. Aini, Analisis Ekstrak Daun Kelor (Moringa Oleifera) pada Pengobatan Diabetes Militus, I. Aceh: Syiah Kuala University Press, 2019.

[22] J. MS, Sitorus, and N. Katharina, Cegah Malnutrisi Dengan Kelor, I. Yogyakarta: Kanisius, 2012.

[23] F. Farooq, M. Rai, A. Tiwari, A. A. Khan, and S. Farooq, "Medicinal properties of Moringa oleifera: An overview of promising healer Medicinal properties of Moringa oleifera: An overview of promising healer," J. Med. Plants Res., vol. 6, no. 27, pp. 4368-4374, 2012, doi: 10.5897/JMPR12.279.

[24] K. T. Mahmood, T. Mugal, and I. U. Haq, "Moringa oleifera: A natural gift-a review," J. Pharm. Sci. Res., vol. 2, no. 11, pp. 775-781, 2010.

[25] S. I. Manuwa, A. M. Sedara, and F. A. Tola, "Design, fabrication and performance evaluation of moringa (oleifera) dried leaves pulverizer," J. Agric. Food Res., vol. 2, no. December 2019, p. 100034, 2020, doi: 10.1016/j.jafr.2020.100034.

[26] S. Diatta, "Supplementation For Pregnant And Breast-Feeding Women With Moringa Oleifera Powder," in Dar es Salaam, 2001, pp. 8-9.

[27] H. Nugraheni, S. Indarjo, and Suhat, Promosi Kesehatan Berbasis Sekolah. 2018.

[28] M. Reber, Development during Middle Childhood: The Years from Six to Twelve, vol. 7, no. 2. 1986.

[29] I. Muflihatin and G. Purnasari, "Organoleptic Properties and Acceptability of Modisco With Moringa Leaf Flour," Second Int. Conf. Food Agric., vol. 2, pp. 570-577, 2019.
[30] R. J. Coller and A. A. Kuo, "Social Determinants of Child Health," Child Heal., no. September, pp. 79-110, 2015, doi: 10.1093/med/9780199309375.003.0005.

[31] P. P. S. Sugiani and G. D. Kusumayanti, "Makanan Padat Gizi Solusi Solusi Sehat Mengatasi Kekurangan Gizi Pada Anak,” J. Ilmu Gizi, vol. 2, no. 2, pp. 125-128, 2011.

[32] Fadliyah, L. R. Kartikasari, and D. Indarto, "Malnutrition treatment of adolescent girls using Moringa chocolate cookies," AIP Conf. Proc., vol. 2021, no. October 2018, 2018, doi: 10.1063/1.5062806.

[33] V. S. Srikanth, S. Mangala, and G. Subrahmanyam, "Improvement of Protein Energy Malnutrition by Nutritional Intervention with Moringa Oleifera among Anganwadi Children in Rural Area in Bangalore , India," nternational J. Sci. c Study, vol. 2, no. 1, pp. 32-35, 2014.

[34] U. Zongo, "Effect of Moringa Leaves Powder Consumption on Young Children Nutritional and Serum Retinol Status in Burkina Faso Rural Area," Int. J. Nutr. Food Sci., vol. 7, no. 4, p. 148, 2018, doi: 10.11648/j.ijnfs.20180704.16.

[35] J. Allo, S. Sagita, R. R. Woda, and C. O. Lada, "Effect of Moringa oleifera leaf powder supplementation on weight Kupang regency," World Nutr. J., vol. 04, no. 1, pp. 56-62, 2020, doi: 10.25220/WNJ.V04.i1.0009.

[36] A. E. Shija, S. F. Rumisha, N. M. Oriyo, S. P. Kilima, and J. J. Massaga, "Effect of Moringa Oleifera leaf powder supplementation on reducing anemia in children below two years in Kisarawe District, Tanzania," Food Sci. Nutr., vol. 7, no. 8, pp. 2584-2594, 2019, doi: 10.1002/fsn3.1110. 